\title{
WestVirginiaUniversity
}

THE RESEARCH REPOSITORY @ WVU

Volume 117 | Issue 1

Article 5

September 2014

\section{Restraining the Hand of Law: A Conceptual Framework to Shrink the Size of Law}

Bryan Druzin

Chinese University of Hong Kong

Follow this and additional works at: https://researchrepository.wvu.edu/wvlr

Part of the Constitutional Law Commons, and the Contracts Commons

\section{Recommended Citation}

Bryan Druzin, Restraining the Hand of Law: A Conceptual Framework to Shrink the Size of Law, 117 W. Va. L. Rev. (2014).

Available at: https://researchrepository.wvu.edu/wvlr/vol117/iss1/5

This Article is brought to you for free and open access by the WVU College of Law at The Research Repository @ WVU. It has been accepted for inclusion in West Virginia Law Review by an authorized editor of The Research Repository @ WVU. For more information, please contact ian.harmon@mail.wvu.edu. 


\title{
RESTRAINING THE HAND OF LAW: A CONCEPTUAL FRAMEWORK TO SHRINK THE SIZE OF LAW
}

\author{
Bryan Druzin*
}

\begin{tabular}{|c|c|}
\hline & ABSTRACT \\
\hline I. & INTRODUCTION.. \\
\hline \multirow[t]{5}{*}{ II. } & THE CASE FOR MINIMALISM ..... \\
\hline & A. Assumptions and Starting Points ..... \\
\hline & The Benefits of Minimalism ................................ \\
\hline & C. The Minimalist Approach to Economic Regulation....... \\
\hline & D. The Liability of Ideology-Both Left and Right... \\
\hline \multirow[t]{6}{*}{ III. } & ARTICULATING A FRAMEWORK FOR LEGISLATIVE MINIMALISM ...........73 \\
\hline & 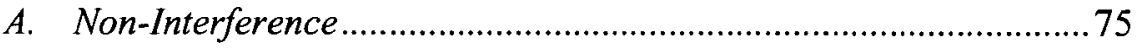 \\
\hline & Formalizing..... \\
\hline & C. Fine-Tuning ................. \\
\hline & D. Dismantling........................... \\
\hline & 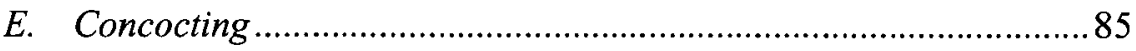 \\
\hline \multirow[t]{8}{*}{ IV. } & 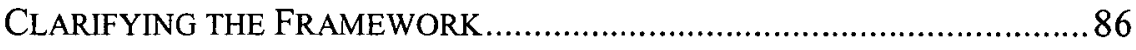 \\
\hline & A. A Tabulated Comparison of the Strategies .................................86 \\
\hline & B. Contract: A Paragon of Legislative Minimalism... \\
\hline & 1. Non-Interference in Contract .......................... \\
\hline & 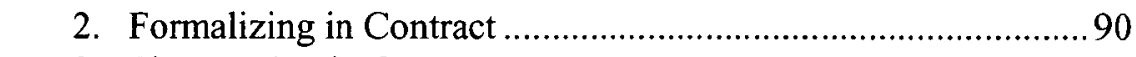 \\
\hline & 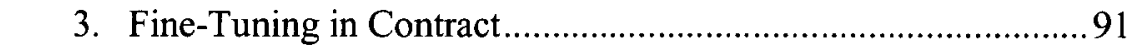 \\
\hline & 4. Dismantling and Concocting in Contract ................................92 \\
\hline & C. Beyond Law: A Wide Breadth of Potential Application ................. 94 \\
\hline$V$. & 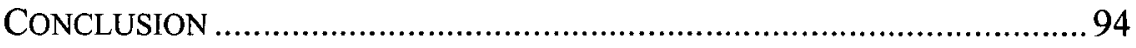 \\
\hline
\end{tabular}

\begin{abstract}
There is a fierce ideological struggle between two warring camps: those who rally against expansive government and those who support it.

* Assistant Professor of Law, The Chinese University of Hong Kong. For their deeply insightful comments, I am deeply indebted to Eric Posner at the University of Chicago; Richard Epstein at NYU; Andrew Simester at University of Cambridge; Julien Webb at Warwick; and Stephen Hall, Xi Chao, Julien Chaisse at the Chinese University of Hong Kong. As well, the drafting of this paper was helped greatly by Direct Grant CUHK funding.
\end{abstract}


Clearly, the correct balance must be struck between the extremes of legislative over-invasiveness and the frightening total absence of legal structure. This paper articulates a framework that allows for legislative parsimony-a way to scale back state law in a way that avoids lurching to unnecessary extremes. I assume the libertarian premise that law should strive to encroach as minimally as possible upon social order, yet I argue that we must do this in a highly selective fashion, employing a range of legislative techniques. I call this approach legislative minimalism. The strength of legislative minimalism is its pragmatic flexibility: different situations will allow for different degrees of minimalism. The paper creates a taxonomy of legislative strategies, outlining five distinct strategies. This taxonomy provides a conceptual foundation to help guide policymakers faced with the question of how best to legislate-or more accurately, how much to legislate.

\section{INTRODUCTION}

Sometimes the most effective form of action is no action at all - or at least as little of it as possible. Consider gardening. The experienced gardener knows that over-gardening can stifle growth. Different situations call for different degrees of tending: sometimes all that is needed is a bit of trimming, sometimes a little invasive weeding, and occasionally what is required is uprooting the entire plant. The trick is in knowing precisely how much "interference" is needed: too little and one's garden will become a disordered mess; too much and one's garden will wither away and die. What is true for the natural ordering of plants is true for the natural ordering of society. Most social order is a natural process. ${ }^{1}$ Imposed social order, that is order created and imposed through the legislative authority and coercive mechanisms of the state, is but the formal tip of a colossal iceberg. ${ }^{2}$ Beneath this surface lies a deep ocean of social norms and customary rules that structure society. ${ }^{3}$ I will refer to

\footnotetext{
1 Indeed, the highest levels of social order are, in fact, found in the insect world, such as with ant colonies and wasp nests. Theories of Social Order: A ReAder 3 (Michael Hechter \& Christine Horne eds., 2d ed. 2009). I use Jon Elster's definition of social order here: stable, predictable behavioral patterns and general cooperative behavior. See JON ELSTER, THE CEMENT OF SOCIETY: A STUdY OF SOCIAL ORDER 1 (1989).

2 Throughout the discussion, the term "the state" is meant to include not only administrative and legislating bodies but also judge-made law.

3 Indeed, most social order is maintained not through state-enforced law but through social norms. Paul G. Mahoney \& Chris W. Sanchirico, Competing Norms and Social Evolution: Is the Fittest Norm Efficient?, 149 U. PA. L. REv. 2027, $2027-28$ (2001); see also, e.g., Robert C. Ellickson, The Evolution of Social Norms: A Perspective from the Legal Academy, in SOCIAL NoRMS 35 (Michael Hechter \& Karl-Dieter Opp eds., 2001) (discussing how social norms arise, persist, and change).
} 
this broadly as customary social order (I use this term henceforth). ${ }^{4}$ It would be a mistake to underestimate the vitality and significance of customary social order: throughout most of our species' history, custom, not formal law, has preserved social order. ${ }^{5}$ Customary social ordering is an unremitting process, surging upwards through the myriad cracks of social intercourse. It is undesigned order - the consequence of social interaction. While the footprint of imposed legal order is large, it dwarfs in comparison to the vast social complexity that remains completely untouched by the instruments of formal law. ${ }^{6}$ At the end of the day, the vast majority of social patterning is neither designed nor regulated.

When one begins to think along these lines, the question that invariably presents itself is: to what extent should formal law interfere with the natural mechanics of social order at all? Clearly, in some areas it intrudes quite a lot, in others, very little. Just how much of society should be subject to the hand of law rather than left to the natural ordering force of custom? Do we want the state to regulate every facet of social existence: family life, sexual practices? What if, for example, the aggregate productivity of society could be substantially improved if each of us slept at least eight hours a night? Would the state then be justified in legislating a societal bedtime? ${ }^{7}$ On the other hand, there are social dynamics that clearly require massive doses of regulation: black markets, organized crime, racial discrimination, etc. The question of how far law should extend itself goes to the very heart of our relationship with government for it is through law that the state asserts the most direct and most powerful influence over our lives. Law is like the corrective hand of a gardener: sometimes it is needed to save the life of a plant, to nurture and sustain it, but equally, it needs to know when to pull back and defer to natural processes. For over-gardening, overwatering, and over-fertilizing the soil-all this will also

4 Customary social order, as it is used here, refers to fixed social patterning on various levels of complexity, from simple norms of conduct (e.g. queuing norms) to quite intricate systems of order (e.g. customary international rules of war). Throughout, I juxtapose this with "imposed social order," i.e. social order created through formal law. The terms social patterning, social ordering, self-ordering systems, customary system, or even just system are used here interchangeably with customary social order. Friedrich Hayek uses the term spontaneous order. See F. A. Hayek, The Constitution of Liberty 160 (1960) [hereinafter Hayek, The CONSTITUTION OF LIBERTY]. This could also be used here.

5 See David Ibbetson, Custom in Medieval Law, in The Nature of Customary Law: Legal, Historical and Philosophical Perspectives 151, 158 (Amanda Perreau-Saussine \& James B. Murphy eds., 2007).

6 I have discussed the self-ordering nature of customary law elsewhere, arguing that it may be strategically manipulated to serve public policy ends. See Bryan H. Druzin, Planting Seeds of Order: How the State Can Create, Shape, and Use Customary Law, 28 BYU J. PuB. L. 373 (2014).

7 It is undeniable that reproduction patterns have clear, large-scale societal implications. Could state regulation of such patterns be justified? China's one-child policy is one answer. Many disagree. 
kill a plant. As the skilled hand of the gardener must be measured, so should the hand of law. It should not overreach, yet at the same time, it should not fail to extend itself where necessary.

The position that law overreaches has been widely argued. Indeed, the idea has great purchase in certain circles. Anarchists, libertarians, conservative economists, and some legal scholars fervently contend that too much social regulation undermines the productivity, potential, and even the basic freedom of the very society it seeks to regulate. ${ }^{8}$ These voices call to restrain (or with respect to anarchists destroy) the hand of law. This paper takes these claims seriously. The discussion that follows is sympathetic to their position (albeit in its technical rather than ideological form). ${ }^{9}$ For the purposes of this paper, I take the general argument as already valid. My job, as I set it out for myself, is not really to make a case for why we should minimize regulation (I mostly assume this leg of the argument); the focus of this paper, rather, is how to go about doing it. If we take the minimalist position as legitimate, the question arises: what are we to do about it? This question lies at the center of a fierce ideological struggle between two warring camps: those who rally against expansive government and those who support it. Clearly, the correct balance must be struck between legislative over-invasiveness on the one hand and a frightening total absence of formal legal structure on the other. Put simply, this paper proposes to split the difference. It articulates a framework that allows for legislative parsimony - a way to scale back state law in a way that avoids lurching to unnecessary extremes. My thesis in a nutshell is this: wherever feasible, we should strive to encroach as minimally as possible upon customary social order, yet this may be done in a highly selective, strategic fashion, employing a range of legislative techniques. I call this approach legislative minimalism. ${ }^{10}$ The strength of legislative minimalism is in its pragmatic

8 As this literature is vast, I refer the reader to the more prominent theorists in this vein. While not a comprehensive list, see the work of Pierre-Joseph Proudhon and Lysander Spooner (early anarchism); Murray Rothbard and Robert Nozick (libertarianism); Friedrich Hayek and Milton Friedman (economics); and Richard Epstein and Robert Cooter (law). See also the literature on overcriminalization. For a good introduction to this literature, see Sanford H. Kadish, The Crisis of Overcriminalization; More on Overcriminalization; and The Use of Criminal Sanctions in Enforcing Economic Regulations, in BLAME AND PUNISHMENT: ESSAYS IN THE CRIMINAL LAW 21, 21-61 (Sanford H. Kadish ed., 1987).

9 I draw this distinction because anarchists and libertarians often make a normative argument against the state, contending that the state is a constraint on personal liberty and is either entirely or largely illegitimate. I do not wish to engage in such arguments here. In fact, I fear that such normative claims only cloud the issue. See infra Part II.D (discussing the hazards of ideology).

10 The term "legislative minimalism" has been employed before yet in a somewhat ad hoc manner connoting various meanings. As such, some clarification is needed. Legislative minimalism as understood here is wherever the state, to whatever degree, strategically incorporates customary social order. This may be contrasted with the concept of legislative maximalism where the state disregards the natural patterning of spontaneous order and instead simply imposes top-down legal order. For scholarship where the term has previously appeared 
flexibility. Different situations will allow for different degrees of minimalism. As such, there is not a single strategy of legislative minimalism; rather, there are several. This paper creates a taxonomy of strategies, outlining five ways in which legislative minimalism may be applied. Taken together, these five strategies provide a conceptual foundation to guide policymakers faced with the question of how best to legislate-or more to the point, how much to legislate. Which strategy is most appropriate should be decided on a case-by-case basis. The trick is in knowing how, like the gardener, the state can skillfully manage customary social ordering and just what dose of minimalism is appropriate.

The hand of law will always extend somewhere along a continuum of intrusion. This is unavoidable. The question is merely in choosing the most appropriate degree of intervention. This being the case, it becomes that much more imperative that we articulate a clear, conceptually rigorous framework for dealing with customary patterning. The contribution of this paper is that it provides such a framework - it provides clarity. In actual fact, the law already deals heavily in customary order, employing different degrees of regulatory intrusion as it builds upon and modifies pre-existing patterns of social order. Yet this is not done in a consistent or coherent fashion. The taxonomy this paper constructs systematizes this entire process. Armed with this conceptual framework, lawmakers will be clear from the outset as to what legislative approach is most suitable to the task at hand, and this clarity will guide them in more skillfully formulating legislation (or not formulating legislation as the case may be). What is currently lacking is a lucid set of instructions to help lawmakers determine where exactly the line of legislative intrusion should be drawn. It is thus important to have at our disposal a clear and comprehensive framework for minimalism even if that means we find sometimes that minimalism is not at all what is needed.

My argument proceeds in three parts. Part II begins by clarifying some foundational assumptions made in the paper and then briefly lays out the case for minimalism. Yet this is not the focus of the paper. Parts III and IV is where the paper offers a fresh contribution to the literature. Part III articulates a framework for legislative minimalism, creating a detailed taxonomy of strategies. Part IV then further clarifies this framework, discussing how these strategies are in fact already at work within the realm of contract. Indeed, in

conveying extremely divergent meanings, see, for example, Ian C. Bartrum, Same-Sex Marriage in the Heartland: The Case for Legislative Minimalism in Crafting Religious Exemptions, 108 MiCH. L. REV. FIRST IMPRESSIONS 8 (2009), http://www.michiganlawreview.org/assets/fi/108/ bartrum.pdf (suggesting that the Iowa legislature should allow the courts to craft religious exemptions regarding same-sex marriage); Mila Sohoni, The Idea of "Too Much Law," 80 FORDHAM L. REV. 1585 (2012) (claiming that federal laws and regulations are too numerous). This should also not be confused with "judicial minimalism," a term popularized by Cass Sunstein that relates to a form of constitutional interpretation. See CASS R. SUNSTEIN, ONE CASE AT A TIME: Judicial MINIMALISM ON THE SUPREME COURT (2001). 
that the state has traditionally employed a "light touch" approach in contract; the law of contract is a terrific case study in how legislative minimalism may be applied across the full spectrum of law.

\section{THE CASE FOR MINIMALISM}

\section{A. Assumptions and Starting Points}

This paper embraces certain assumptions and starting points that need to be made clear from the outset. First, as I said in the introduction, for the purposes of the discussion, I take the claims of those who call to shrink the size of law seriously. This assumption is open to attack on both normative and factual grounds. However, let me preemptively defend against such criticisms. I do this not because the argument for minimalism is closed to debate; rather, I do this because this is not really the paper's focus. My focus, rather, is in crafting a framework to effectuate minimalism that is nuanced, strategic, and avoids lurching to unnecessary extremes. Thus, I take as my starting point that we do indeed want to shrink the size of law and then offer a way to get there. As such, I am laboring under two assumptions, the first descriptive and the second normative. The first is that imposed social order is generally more vulnerable to inefficiencies (for reasons I will explain). The second assumption, which flows from the first, is that we should, therefore, only impose order where it is absolutely necessary. ${ }^{11}$ Both these assumptions relate to a familiar controversy (the role of government), and the paper does not add anything startlingly new on this front-it is taken as a working premise that the technical argument for minimalism holds merit. Rather, the contribution of this paper resides mostly in Parts III and IV where a clear taxonomy for legislative minimalism is set out, scrutinized, and dissected.

A general theme emerges from the discussion: wherever it is feasible, legislative minimalism should be preferred over its opposite, legislative maximalism. This is because each time we successfully minimize the state's intrusion into natural social patterning, we arguably reduce the risk of messing things up. Hence, when faced with the choice whether or not to take legislative action, we should err on the side of caution and favor minimalism. Yet it is important to note that just because a system of customary social order arises bottom-up, this is no guarantee that it is optimal or even desirable. ${ }^{12}$ It would be profoundly naive to assume that customary social ordering is always optimal. Such order may be grossly inefficient, unjust, or may simply stand to

\footnotetext{
11 Indeed, this is how I read Hayek. The basic premise of his work is thus embraced here.

12 Yet, arguably, its decentralized, organic genesis does give it a certain consistent advantage over its top-down competition in that such complexity is better suited to spontaneous processes. See infra Part II.B for a fuller discussion of this under the concept of design efficiency.
} 
benefit from some minor tinkering. ${ }^{13}$ Just how much tinkering is needed will vary. I employ a very parsimonious definition of efficiency: "efficient" simply means that the system of order is able to effectively achieve whatever purpose the system is geared to achieve. ${ }^{14}$ As I use it here, there are thus degrees of efficiency: the more effectively a system can achieve its purpose, the more we can say it is efficient. For example, the more a system of traffic order can achieve an uncongested traffic flow, the more it may be said to be efficient. If a system achieves its purpose but this can be improved upon (i.e. traffic congestion could be further reduced), then it suffers from inefficiency. In using the term, I do not necessarily mean strict economic conceptions of efficiency such as allocative efficiency, Pareto efficiency, distributive efficiency, or productive efficiency (although it may certainly include any or all of these). Perhaps another way to think of this that may be useful is in terms of "effectiveness" or "efficacy."

The taxonomy the paper constructs offers a new, or at least clearer, approach to an old debate and in this respect may prove interesting. What legislative minimalism entails are degrees of minimalism that span a continuum reflecting the level of involvement versus disengagement; it relates to the degree to which top-down law "intrudes" upon customary social order. The approach is unique in that it proposes graduated degrees of minimalism and articulates specific strategies to effectuate this. As such, it assumes a less dogmatic attitude towards the role of government. ${ }^{15}$ Robert Nozick once remarked that "[t]he fundamental question of political philosophy, one that precedes questions about how the state should be organized, is whether there should be any state at all." 16 For our purposes we can tweak this slightly: the most fundamental question for us, one that precedes even how formal law should be organized, is whether there should be any formal law at all. My thesis is that this is not an all-or-nothing proposition. It is a question that may be answered with different intensities of formal law on a case-by-case basis

\footnotetext{
13 While I better define "inefficiency" below, as for the term "unjust," I do not proffer any definition. The term unjust as it is used here may mean any number of things depending upon a society's particular goals and objectives. This may range from equitable resource distribution to maximization of productivity. For our purposes, what a society deems as just is of relevance only to the extent that such conceptions will influence what is seen to be the purpose of a system, shaping our determinations of efficiency. For example, in the case of traffic order, its purpose may be fluid traffic flow, yet it may just as well be safe traffic flow. Whether a system is judged efficient will depend upon the purpose we assign to it, and this is unavoidably bound up with normative views. Where normative concepts influence our understanding of efficiency, they will determine the policy decision whether to intervene and to what extent.

14 And without producing unanticipated negative externalities.

15 This can be thought of as a "thin" model of minimalism in that it permits degrees of topdown law from the lightest kinds of minimalism to the heaviest forms of legal maximalism, if indeed that is what is required.
}

16 ROBERT NozICK, ANARCHY, STATE, AND UTOPIA 4 (1974). 
depending on the social pattern we are dealing with. Before wading deeper into our discussion, I shall briefly outline the case for why legislative minimalism is something beneficial we should seek to implement on a policy level. However, as this position is assumed to already hold merit, I do this really more to contextualize the discussion than to advance specific arguments for minimalism. What follows is the standard technical argument for minimalism. With this in mind, let us consider some of the benefits that may be gleaned from a minimalist approach.

\section{B. The Benefits of Minimalism}

It is important that we are clear that when we speak of customary social order we are in fact discussing something that can take a variety of forms. Customary social order can range from simple norms of conduct (e.g. students' self-assigning seats in a classroom or queuing norms) to extremely complex and intricate systems of normative order (e.g. the driving norms of a thirdworld city or the customary rules of international armed conflict). ${ }^{17}$ Regardless of the form it takes, however, customary social order offers some practical advantages over imposed social order. Because customary social order arises from an active discourse between parties rather than from being imposed from above, the social rules that it produces are often more efficient, ${ }^{18}$ robust,

17 The machinery of customary social ordering has been widely studied: various mechanisms help foster and sustain its emergence. I have explored this theme elsewhere. See generally Bryan H. Druzin, Opening the Machinery of Private Order: Public International Law as a Form of Private Ordering, 58 ST. LouIS U. L.J. 423 (2014) (positing that positive duties help sustain commercial contracts and international treaties by establishing trust through repeated rounds of signaling). See also Druzin, supra note 6 (discussing the self-ordering nature of customary law and arguing that it may be strategically manipulated to serve public policy ends). The conclusions of game theorists, evolutionary biologists, legal anthropologists, and sociologists all fall along similar lines. Repeated interaction allows for the possibility of very sophisticated forms of coordination without third-party enforcement because the shadow of future encounters can support a cooperative equilibrium. Given sufficient repeated interaction, individuals can rely on the threat of retaliation and reputational costs as informal enforcement mechanisms to encourage rule compliance. On the carrot side of the ledger, the element of reciprocal benefit that often comes with repeated interaction reinforces such arrangements, cementing the social rules that emerge. Much of the game theory literature addresses the impact of repeated games as a solution to the prisoner's dilemma. I refer the reader to the foundational work regarding this idea, see Robert Axelrod \& William D. Hamilton, The Evolution of Cooperation, 211 SCI. 1390 (1981); Robert Axelrod, The Emergence of Cooperation Among Egoists, 75 AM. PoL. SCl. REV. 306 (1981). The take-away point here is that customary social order is a naturally occurring phenomenon. So long as the correct ingredients are present, it may manifest.

18 But see H. Peyton Young, Social Norms 6 (Univ. of Oxford Dep't of Econ. Discussion Paper Series, Paper No. 307, 2007), available at http://www.economics.ox.ac.uk/materials/ working_papers/paper307.pdf (pointing out that many social norms are demonstrably inefficient). 
internalized, ${ }^{19}$ and self-enforcing. Where the rules prove self-enforcing, the enforcement burden on the state may be lightened. ${ }^{20}$ This alone is a significant advantage. Yet the central benefit of customary social order over that of topdown law is that it solves the problem of informational complexity. Informational complexity is the idea that when a high level of complexity is reached in any given system, it becomes exceedingly difficult, if not impossible, for one individual to know or process all the data relevant to a decision. ${ }^{21}$ This is a serious problem, one to which lawmaking is extremely vulnerable. The sheer complexity of law, a vast system of evolving rules and interrelated concepts, can be so difficult to grasp in its entirety that it often leads to design errors that produce unanticipated negative externalities. Put simply, it can cause us to make bad law. We can term this design error. ${ }^{22}$ It is a working premise of this paper that design error abounds in the law.

It is, as Friedrich A. Hayek contends, an extraordinarily difficult task to design organized complexity because it is impossible for one mind to grasp all

19 That is, there arises an underlying sense of universal duty to follow the norm-the "ought to" in a Humean sense. See David HuME, A TREatise of Human NATURE 335 (1739). When a norm is internalized, it gives rise to the feeling that it is implicitly valid. As Eric Posner says, "[P]eople bound by [norms] feel an emotional or psychological compulsion to obey the norms; norms have moral force." Eric A. Posner, Law, Economics, and Inefficient Norms, 144 U. PA. L. REV. 1697, 1709 (1996). At a more advanced stage, the process can achieve the standing of opinio juris, the belief that a particular action carries a legal obligation.

20 The reader should note that the focus here is not upon self-enforcement. Self-enforcement is well-studied, particularly within the field of evolutionary game theory. Yet, with the exception of the strategy of Non-interference, this important aspect of customary social order is left out of the discussion.

21 This idea formed the better part of the life's work of the economist Friedrich A. Hayek. For his early and perhaps best-known work on the subject, see F. A. HAYEK, THE ROAD TO SERFDOM: TEXT AND DOCUMENTs 95 (Bruce Caldwell ed. 2007) [hereinafter HAYEK, THE ROAD TO SERFDOM]; see also $1 \mathrm{~F}$. A. HAYEK, LAW, LegisLation AND LiberTy: A New STATEMENT OF THE Liberal PRINCIPLES OF JUSTICE AND POLITICAL ECONOMY 15 (1973) (discussing the impossibility of knowing and using all relevant facts) [hereinafter HAYEK, LAW, LEGISLATION AND LIBERTY]. It is an extension of the economic calculation problem proposed by Ludwig von Mises, which decries the use of centralized planning in place of a market-based allocation of the factors of production. See Ludwig VON Mises, ECONOMIC CALCulation IN THE SOcialist COMMONWEALTH (1920) (discussing the increase in specialization and complexity of society); see also JoHn C. W. TOUCHIE, HAYEK AND Human Rights: Foundations fOR A Minimalist APPROACH TO LAW 94-95 (2005).

22 Design error is measured by the inability of a system of order, due to structural-design reasons, to effectively achieve its purpose without producing unanticipated negative externalities (system efficiency). The more it is unable to do this, the more we can say the system suffers from design error. Take an artificial heart as an example. If its purpose is to pump a sufficient flow of blood through the body to keep the recipient alive, vigorous, and in good health, then it can be said to suffer from design error if (1) the patient dies, if (2) the recipient lives but is not in a vigorous condition, or if (3) the patient lives but, say, develops serious blood clots (unanticipated negative externalities). In this respect, design error is a matter of degree. 
the relevant information. ${ }^{23}$ The problem of informational complexity was Hayek's central critique of socialism and central planning (and legislation), a concept that assumed center stage throughout the whole of his work, featuring prominently in his writings on spontaneous order. ${ }^{24}$ Many argue that the failure of the socialist project with its reliance on central planning was an illustration of informational complexity on a catastrophic level. ${ }^{25}$ Systems theory, particularly Niklas Luhmann's autopoietic theory of law, reaches similar conclusions regarding system complexity and the limitations of centralized design. ${ }^{26}$ There is an implicit danger in tinkering with systems that we do not fully understand. Lon L. Fuller's famous concept of polycentricity delivers a similar verdict on the constraints of system complexity. Fuller famously describes the difficulty of tinkering with interlocking complex networks with the image of pulling on a spider's web: picking at one strand will invariably produce unanticipated tensions throughout all the other strands of the web. ${ }^{27}$ Indeed, this can be thought of as something akin to tinkering with the weather.

Indeed, the problem of informational complexity has been noted with regards to a sweeping range of order, from centrally-planned economies to ecological as well as complex biological systems. Law is not exempt. Indeed, informational complexity is a big problem for legislation. The unending difficulty in applying statute to real-world situations is stark testament to this challenge. These difficulties, it is argued here, stem directly from the problem of informational complexity on a wide scale. ${ }^{28}$ When crafting law, it is simply

23

See HAYEK, THE ROAD TO SERFDOM, supra note 21, at 95. Hayek calls the idea that all the relevant facts can be known to one mind a "synoptic delusion." See HAYEK, LAW, LEGISLATION AND LIBERTY, supra note 21, at 14. He terms this form of thinking "constructivist rationalism." Id. at 5; see also ERIC ANGNER, HAYEK AND NATURAL LAW 51 (2007) (explaining, in very clear terms, Hayek's thinking in this respect).

24 Hayek borrows the phrase from Michael Polanyi, explaining that: "Such an order... cannot be established by central direction .... It is what $\mathrm{M}$. Polanyi has called the spontaneous formation of a 'polycentric order': 'When order is achieved among human beings by allowing them to interact with each other on their own initiative... we have a system of spontaneous order in society." ' HAYEK, THE CONSTITUTION OF LIBERTY, supra note 4, at 160.

25 See, e.g., Robert D. Cooter, Against Legal Centrism, 81 CALIF. L. REV. 417, 418 (1993) (reviewing Robert C. Ellickson, Order Without LaW: How Neighbors SetTle Disputes (1991)).

26 Guilherme Vasconcelos Vilaça, From Hayek's Spontaneous Orders to Luhmann's Autopoietic Systems, 3 STUD. IN EMERGENT ORD. 50, 52-53 (2010), available at docs.sieo.org/ SIEO_3_2010_Vilaca.pdf.

27 See Lon L. Fuller, The Forms and Limits of Adjudication, 92 HARV. L. REV. 353, 394 (1978); see also RICHARD A. EPSTEIN, SIMPLE RULES FOR A COMPLEX WORLD (1995) (arguing insightfully that legal complexity generates excessive costs that may be mitigated through a process of rule-simplification).

28 Hayek stresses that this weakness is implicit in statute. See Aeon J. Skoble, Hayek the Philosopher of Law, in THE CAMBRIDGE COMPANION TO HAYEK 171, 176-77 (Edward Fescr ed., 2006). 
impossible to anticipate all the consequences that will flow from its application. This is arguably the fundamental shortcoming to deliberate design writ largeat best, lawmakers can make only educated guesses based on the limited information they have available, but as the information is limited, their understanding is limited. Lawmakers lack the requisite knowledge of all relevant concrete circumstances. The process of legislation is thus extremely prone to producing design errors. It is a project bound to periodically fail. While our focus here is primarily upon statute, case law is also straightjacketed by similar constraints. Notwithstanding the largely organic nature of stare decisis, case law also suffers (albeit to a lesser degree) from the inherent limitations of imposed social order caused by informational complexity. This is clearly evidenced by the tangle of conceptual knots so often created by judgemade law. While the incremental nature of case law makes it arguably less susceptible to the problem of informational complexity, it cannot match the design efficiency of most customary social order, and as such, also often produces very bad law. ${ }^{29}$ It is because of this that the law, particularly the common law, is locked within a constant state of modification and rectification as design errors continually come to light. Judge-made law that results from precedent is just imposed social order on a more localized level as compared with statute and so, while superior to statute in this respect, to a great extent its negative effects, because they are less far-reaching, are just less obvious. It does not mean they are not present.

We see the problem of informational complexity with systems of organization at all levels. Notwithstanding our good intentions, attempts at improving a system's design by tinkering with the mechanics of natural ordering frequently end in us just making a mess of things. Indeed, it is as the sociologist Robert K. Merton famously put it, the irresolvable dilemma of unintended consequences. ${ }^{30}$ As such, it seems wise, to the extent that it is viable, to trust the natural process of social ordering and not rush to interfere unless it is the case that there are clear and compelling reasons to do so. The more the state seeks to regulate social order the wider the door is swung open to the potential of creating bad law. As such, the hand of law should only extend itself where the benefits of doing so are assured. This is particularly true when dealing with highly complex systems where the impact of one's actions is difficult to anticipate. Economic hyper-lexis is perhaps the most familiar illustration of this. The problem of informational complexity, many right-

\footnotetext{
29 Hayek places (I feel unwarranted) faith in the ability of the common law to overcome the problem of informational complexity. See BRIAN Z. TAMANAHA, ON THE RULE OF LAW: History, POLITICS, THEORY 69 (2004). As many commentators point out, Hayek seems to conflate customary law and case law in his analysis. See Skoble, supra note 28, at 175 (referencing John Hasnas' critique of Hayek in this respect). In any case, as a solution to the complexity problem, customary social order far exceeds the incremental decision-making process of the common law.

30 Robert K. Merton, The Unanticipated Consequences of Purposive Social Action, 1 AM. SoC. REV. 894, 898 (1936).
} 
leaning economists argue, ${ }^{31}$ fundamentally precludes the possibility of successful central market planning (this is discussed at greater length in the section that follows). Indeed, some scholars frame this problem precisely in the economic terms of legal centralism versus legal decentralism. Lawmaking is conceptualized like commodity production: it can be either centralized or decentralized. ${ }^{32}$ Robert $\mathrm{D}$. Cooter, for example, argues that the information and incentive constraints upon government officials demand that modern society strive to incorporate decentralized forms of lawmaking. ${ }^{33}$ Statute can be understood as the epitome of centralized lawmaking, case law less so; yet customary law is the purest form of decentralized legal order, as a central rulemaking authority is entirely absent. Customary social order solves the problem of information complexity because it is not the product of any central design: it arises bottom-up in a purely organic fashion. As a result, customary social order is less susceptible to design error, much like other natural ordering systems that survive the winnowing effect of an evolutionary-like process (organisms, plants, cells, ecological systems). Its survival as a customary system is a strong indication that it does not suffer from significant design errors. $^{34}$

\section{The Minimalist Approach to Economic Regulation}

This is perhaps most visible in the context of economic regulation. Regulatory minimalism in the economic realm can be understood as a subset of the larger project of legislative minimalism. Many systems of customary social order do not imply a market dynamic. Yet, that said, a great deal of social order is subsumed by market forces. At its core, the market is a colossal system of customary social order. ${ }^{35}$ As such, it is not surprising that the question of where

31 I am referring here primarily to the scholars from the Austrian school of economics. For a good general overview of the Austrian school, see Jesús HuERTA DE SOTO, THE AUSTRIAN SCHOOL: MARKET ORDER AND ENTREPRENEURIAL CREATIVITY (2008).

32 See Cooter, supra note 25.

33 See, e.g., id.; see also Robert Cooter, Normative Failure Theory of Law, 82 CORNELL L. REV. 947, 948 (1997) ("[T]he urgency of bottom-up law increases with economic and social complexity. As society diversifies and businesses specialize, state officials struggle to keep informed about the changing practices of people, and people struggle to make lawmakers respond to changing practices. To loosen these constraints on information and motivation, law must decentralize.").

34 Yet it should be noted that evolutionary processes do not guarantee design perfections. Such systems are not exempt from inefficiencies; they just stand a better chance of avoiding them. As such, some sobriety is needed in dealing with the concept of minimalism. As well, this process is completely silent as to the system's normative character. Indeed, the customary social order may result in systems of order that are grossly "unjust" from a normative perspective.

35 Or a multiplicity of systems depending upon how one wishes to conceptualize the market. 
the line for regulatory intrusion should be drawn has engendered so much persistent debate.

Modern calls for deregulation echo the "light-touch" minimalist approach to regulation rooted in the laissez-faire ideology of the 19th century. Cries to roll back state "interference" in the market grew particularly vociferous in the latter half of the 20th century as the intellectual groundwork of the Austrian school of economics took root. Beginning in the 1970s, many economists in the West sounded the call to shrink the size of economic regulation, arguing the virtues of keeping state intervention of economic and social activities to a skeletal minimum. ${ }^{36}$ This provided the intellectual momentum for reformist politicians in Europe and North America (most notably Margaret Thatcher and Ronald Reagan) to dismantle economic regulations throughout the 1980s. Salient examples of this "light-touch" approach could be found in the regulation of international financial markets. Issuance of bonds, derivatives, syndicated loans, hedge funds, and so on, traditionally had no place for domestic or international regulation. The theme was private ordering and, at most, private enforcement of formal, non-statebacked norms. ${ }^{37}$ Referencing the ideas of Hayek, Lawrence H. Summers, former Secretary of the U.S. Treasury and former Chief Economist of the World Bank, captured this understanding, asserting that "the invisible hand is more powerful than the [un]hidden hand. Things will happen in well-organized efforts without direction, controls, plans. That's the consensus among economists. That's the Hayek legacy."

However, the financial crisis of 2007 exposed the limitations of this customs-based system, underscoring the inherent danger in taking minimalism to an inappropriate extreme. In the aftermath of the financial crisis, deregulation has been widely condemned as a failure. Yet it would be a colossal mistake-indeed, it would be intellectual negligence-to simply dismiss the point that these theorists make regarding the dangers of tinkering with complex systems of order. It is a powerful argument, and it finds strong support in many examples well beyond the economic realm. As with most things, the answer likely lies somewhere in the middle. While we can indeed scale back the legislative intrusiveness of the state, we must be careful to not allow this to devolve into an anarchic free-for-all. Different dynamics will allow for different degrees of minimalism. And so it is the case for legislative minimalism writ large. Within the biological realm, this is precisely what the

\footnotetext{
36 See Cooter, supra note 25.

37 For the concept of self-regulation, see Anthony Ogus, Self-Regulation, in 5 ENCYCLOPEDIA OF LAW AND ECONOMICS 587, 587-602 (Boudewijn Bouckaert \& Gerrit De Geest eds., 2000), available at http://encyclo.findlaw.com/9400book.pdf; Anthony Ogus, Rethinking SelfRegulation, 15 OXFORD J. LeGAL STUD. 97, 97-108 (1995).

38 Daniel Yergin \& Joseph Stanislaw, The Commanding Heights: The Battle Between GOVERNMENT AND THE MARKETPLACE THAT IS REMAKING THE MODERN WORLD 150-51 (1998).
} 
practice of medicine does: it modulates the natural processes of the human body. Agriculture alters the natural patterning of ecological systems yet has changed the course of human history for the better. Indeed, most economists advocate for a mixed economy where a decentralized market is gently guided by an element of central planning. ${ }^{39}$ No doubt the same paradigm may be usefully applied to law. We should opt for a more nuanced approach that recognizes that various gradations of state intrusion are possible.

\section{The Liability of Ideology-Both Left and Right}

As such, when appraising the value of minimalism, it is best to put political ideology aside. Unfortunately, this has not usually been the case, and it has led to some very ugly results. On one side, the conversation at times seems hijacked by interest groups that stand to benefit financially from scaling back the scope of regulation within the private sector. For these "partisans" of smaller government, minimalism is a philosophy of mere convenience. Yet in the other camp we have the strident disciples of the state, offering only civility and blind subservience to the rent-seeking, fumbling, and often pernicious force of centralized power. In the academy, the argument against minimalism seems to be winning the day: those who advocate for a minimalist approach have not received the attention due them in academic discourse. ${ }^{40}$ Yet there remains legitimate intellectual footing here. It would be academically reckless to not recognize the legitimacy of the minimalist position. An honest tallying informs us, as is so often the case, that both sides to the dispute merit serious intellectual attention. Rather than interminably debating the advantages of decentralized versus centralized planning, we ought to be discussing the correct mix of the two. ${ }^{41}$ It is important to maintain an even-handed perspective: the implicit liabilities of over-regulation should not be denied, nor should we adopt a position that blindly discounts the important role of the state in sustaining and optimizing social order. The advantage of legislative minimalism is that its stratified character allows for a more realistic balance between the extremes of legislative maximalism on the one hand and the complete absence of formal law on the other. As a policy approach, it thus occupies the sober middle ground between these two poles.

Yet it is very difficult to escape ideology. The general tenor of nonintrusiveness that legislative minimalism brings to the table has clear political resonance. It not only reduces the potential to mess things up through

\footnotetext{
39 See STEPHEN D. TANSEy, Business, INFORMATION TECHNOLOGY AND SOCIETY 79 (2003).

40 Matthew D. Adler \& Eric A. Posner, New Foundations of Cost-Benefit Analysis 2 (2006).

41 See Margaret Jane Radin \& R. Polk Wagner, The Myth of Private Ordering: Rediscovering Legal Realism in Cyberspace, 73 CHI.-KENT L. REV. 1295, 1298 (1998) (making a similar point regarding private ordering in the context of online commerce).
} 
legislative over-intrusiveness (the technical argument), it arguably fosters a freer society that is more in tune with the basic tenets of a modern liberal, pluralistic state (the normative argument). Neo-classical liberal theorists sound this theme loudly, arguing that minimalism is more compatible with liberal principles. ${ }^{42}$ The contention is that in order to allow the exercise of individual freedom, the ambit of state power should be constrained as much as possible. In that customary order is merely a reflection of established norms, the argument goes, such bottom-up order does not coerce in the same oppressive sense as legislated law. ${ }^{43}$ While this argument may be legitimate, unfortunately, ideological incantations of this nature too often inspire an all-or-nothing approach that precludes nuance and obliterates any hope of pragmatic flexibility. Too often, those who advocate slaughtering the state on the altar of individual liberty go too far. This is particularly true for anarchists (of whatever stripe) who call for the complete dismantling of the state.

There is a great deal of intellectual polarization. We must be vigilant against the ideological extremes persistent in our culture, extremes that too often hew fanatically towards a kind of myopic absolutism. Let us avoid being swept away in the surging currents of ideology. Let us approach the question with the view that the problem is not so much paternalism, an encroachment upon personal liberty, or an invisible hand clenched in indifference, but rather that the problem is simply design error. As such, it is better if we divorce the conversation from ideology. Customary social order, if harnessed correctlythat is in a non-ideological and pragmatic fashion-could prove immensely beneficial. ${ }^{44}$ To do this, however, policymakers need to know clearly when it is necessary to extend the reach of regulation and to what degree. For this, a sturdy intellectual scaffolding is required. Constructing such a framework is the goal of the rest of this paper.

\section{ARTICULATING A FRAMEWORK FOR LEGISLATIVE MINIMALISM}

H.L.A. Hart once observed that "[c]ustoms arise, whereas laws are made. ${ }^{" 45}$ From this he concluded it is therefore impossible for custom to ever serve the ends of policymakers. ${ }^{46}$ What Hart failed to appreciate, however, is

42 Hayek in particular makes a strong case along these lines. See generally, HAYEK, LAW, LEgislation AND LiberTy, supra note 21; see also F. A. HAYeK, The FATAL CONCEIT: THE ERRORS OF SOCIALISM (W. W. Bartley III ed., 1991).

43 See Skoble, supra note 28 , at 176-78.

44 I have written elsewhere on the possibly of harnessing the energy of customary law in a strategic fashion. See Druzin, supra note 6.

45 Robert D. Cooter, Decentralized Law for a Complex Economy: The Structural Approach to Adjudicating the New Law Merchant, 144 U. PENN. L. ReV. 1643, 1655 (1996) (citing H. L. A. HART, CONCEPT OF LAW 89-96 (1961)).

46 See H. L. A. HART, CONCEPT OF LAW 89-96 (1961). 
that simply allowing customary social order to arise unimpeded is itself an important policy end. Legislative minimalism, in that it articulates a structured methodology, enables lawmakers to more effectively achieve this. To construct such a methodological framework, however, we must first undertake a reconceptualization of sorts. We should understand legislative minimalism and legislative maximalism not as opposite approaches but rather two extreme ends of a single continuum (see fig. 1 below).

Figure 1. The figure below depicts various forms of legislative minimalism along a continuum of intervention between legislative minimalism and legislative maximalism. These different forms of legislative minimalism are outlined below.

Legislative minimalism

Legislative maximalism

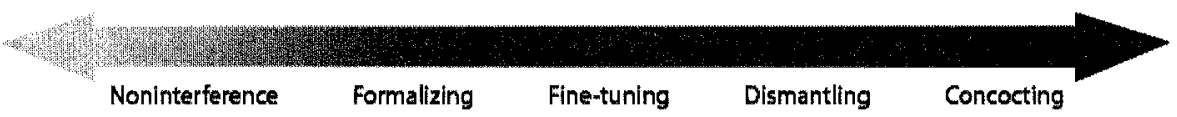

While a policy of pure legislative minimalism is often simply not feasible, unrestrained legislative maximalism can, as we have said, generate very bad law due to the natural constraints imposed by informational complexity. Fortunately, it is not all or nothing: there are gradations of legislative intrusion that may be employed. The state can deal with customary social order in a number of ways, choosing from a variety of strategies. Below, I detail five strategies. Most of these strategies themselves allow for different degrees of intensity, i.e. thinner and thicker forms-they are in a sense themselves mini-continuums. ${ }^{47}$ The degree to which the state can pursue a legislative minimalist approach will depend simply upon the nature of the particular patterns that have emerged. What is required is to first identify if there is a discernible pre-existing pattern of customary social order. If there is, we then need to determine what kind of customary system we are dealing with and apply the legislative minimalist policy that keeps intrusion to a workable minimum while correcting, sustaining, or perhaps strengthening that system, whatever the case may be.

Where customary social order has emerged, lawmakers can do one of five things depending upon the nature of that order: (1) do nothing if the system of rules is functional and adequately efficient; (2) simply formalize the system as is, giving it some enforcement teeth to further bolster its efficacy; (3) tweak

\footnotetext{
47 The strategy of Non-interference does not by its structural nature admit to thin and thick forms. Note that I use the terms light and heavy to describe the continuum of intervention as a whole and the strategies that fall along it. Light strategies are those in the direction of legislative minimalism and heavy strategies are those in the direction of legislative maximalism.
} 
it where necessary if there are inefficiencies; (4) override and dismantle it where it is grossly inefficient (as indeed it may very well be); or (5) fabricate a completely new system of order from scratch. ${ }^{48}$ From a legislative minimalist perspective, the first and second of these options are clearly the best, and the third remains preferable to the fourth, which should only be invoked as a measure of very last resort. The fifth option is clearly the least desirable, as it is highly prone to design error due to the natural constraints of informational complexity. These five approaches are the only ones available to the policymaker. Yet no one has yet articulated this taxonomy, naming, cataloging, and distinguishing clearly between these, the only possible options. This taxonomy recognizes a range of regulatory strategies that stand between the poles of imposed and spontaneous order. On one side we have legislative maximalism, blundering and highly fallible; on the other we have extreme legislative minimalism with its overly-optimistic faith in the efficiency of natural ordering. This paper carves out a vast middle space between these two extremes. Which strategy is most optimal will depend on the particular characteristics of the customary system.

\section{A. Non-Interference}

The first of these five strategies may seem the most radical, but it is, in fact, just the opposite. If the existing rules are determined to already be optimal (or simply sufficiently functional), the state can simply let the system of order function completely free of state intrusion. For ease of reference, we can term this approach Non-interference. In fact, Non-interference is what the law does most of the time: the state does not seek to regulate the vast majority of social ordering. It actually stays well clear of most of it, electing to regulate only a small sliver of existing social order. There exists a vast sea of social rules completely untouched by formal law. These systems of customary social order function all without any need for codification or enforcement. Indeed, the need to formulate and enforce order can be understood as a sign of this natural process failing. ${ }^{49}$ Moreover, formal enforcement is often not even viable. Consider for a moment the impracticality of the state having to enforce something as simple as the rules of queuing or the rules of English grammar. Fortunately, the state does not enforce such regulatory standards nor, more importantly, does it need to. There is no need for the state to regulate queuing.

\footnotetext{
48 Hybrids of these strategies are also possible. This idea of hybrid strategies is examined later in the discussion. See infra Part IV.A.

49 Lon Fuller makes this point nicely, stating that, in its ideal form legal order "works so smoothly that there is never any occasion to resort to force or the threat of force to effectuate its norms." LON L. FUlLeR, Human Interaction and the Law, in THE PRINCIPLES OF SOCIAL ORder: SELECTED ESSAYS OF LON L. FULLER 221 (Kenneth I. Winston ed., 1981); see also Cooter, supra note 33, at 955-57 (discussing how the law affects internalization of social obligations).
} 
It is a reasonably efficient system of social ordering that is mostly selfenforcing. Ticket queuing may be more advantageous (though not necessarily in all situations); however, lining up is sufficiently efficient.

Even where slightly inefficient, interference still may not be worth the cost (cost need not be measured purely in monetary terms). For instance, while customary rules that allow for pushing instead of orderly queuing may be less efficient, this may still not justify interference. The demands involved in regulation may simply be too high. Indeed, the enforcement burden of legislating queuing regulations across society would simply be untenable. ${ }^{50}$ The administrative cost of interfering with low-level systems of customary rules (in this case pushing) must be weighed, employing a cost-effectiveness analysis. ${ }^{51}$ Many systems of customary social order, while imperfect, may not be worth the cost of regulating, making Non-interference for this reason alone a preferable approach.

Of the five options, Non-interference is the most ideal. So long as it is feasible, law should strive to be less intrusive, wherever possible allowing order to function unhindered instead of trying to impose it from above. If the system is functional and does not suffer from gross inefficiencies then a policy of Non-interference is preferable. It is the "safest" approach. This "light" form of intervention is the path endorsed by anarchists and to a large extent by those in the libertarian camp. The state should not interfere: "the best form of government is a government that governs least" (in the case of anarchists, this would be a government that does not exist). ${ }^{52}$ Non-interference is the most extreme form of legislative minimalism. While it is at times feasible and indeed a skillful approach to governance it is quite often simply not a viable option. Formal law has its role to play.

\footnotetext{
50 Although it is not inconceivable and is in fact often performed on the local level. The case of queuing norms in McDonald's in Hong Kong provides a good example. When McDonald's first opened in Hong Kong in 1975, patrons "clumped around the cash registers, shouting orders and waving money over the heads of people in front of them. The company responded by introducing queue monitors ...." James L. Watson, Globalization in Asia: Anthropological Perspectives, in Globalization: Culture and Education IN THE New MillenNium 156 (Marcelo M. Suárez-Orozco \& Desirée Baolian Qin-Hilliard eds., 2004). A customary system of queuing quickly replaced a customary system based upon pushing in McDonald's restaurants. Id.

51 Note that I call for a cost-effectiveness analysis rather than a cost-benefit analysis. This is because assigning monetary value to outcomes would limit our discussion to a specific normative format (economic) at the expense of a more expansive evaluative standard.

52 While this quote (I am paraphrasing) is often attributed to Thomas Jefferson or Thomas Paine, the true source seems to be Henry David Thoreau. See Henry David Thoreau, Civil Disobedience, in ON CIVIL Disobedience: AMERICAN EsSAys, Old AND NEW 11 (1969).
} 


\section{B. Formalizing}

Also a preferable approach for the same reason is our second option: the state can directly take up these spontaneously-formed rules and formalize them. Architects may have a lot to teach lawmakers here. Architects sometimes design large building complexes but wait to fill in the pathways until after observing the natural flow of pedestrian traffic. These informal pedestrian routes are then later paved over as formal walking paths where the pathways have become worn in. ${ }^{53}$ This is a good metaphor for how law can use customary social order. In the same way, where there is sufficient foot traffic (i.e. customary social order), the state may assume the strategy of an architect awaiting the actors to fill in the pathways of legal structure. We can call this form of legislative minimalism Formalizing because it simply grants a formal status to an informal pattern of order. While Non-interference is ideal, Formalizing is often necessary due to free-riding, among other reasons. ${ }^{54}$ The efficiency of customary patterning may be undermined by enforcement problems. This is especially true where an increase in group size sabotages the natural enforcement mechanisms of small-group social order. ${ }^{55}$ This is an old justification for state intervention in social ordering. Indeed, the notion that maintenance of social order through enforcement is a public good goes all the way back to Hobbes. ${ }^{56}$

While a stable, relatively efficient system of customary social order may emerge, persistent cheating along its edges makes Formalizing a relatively non-intrusive, ${ }^{57}$ yet very effective, option for the state. The strategy of Formalizing is, in fact, extremely common. So much so, in fact, that it mostly goes unnoticed. The law largely conforms to existing norms, and these customary rules are given enforcement teeth to preempt the possibility of skewed incentive structures and ensure compliance. This can be done through the threat of criminal sanctions, the threat of fines, or the granting of a right to civil action. Formalizing is simply taking an existing system of order and

53 The concept of this kind of emergence has been linked to theories of urban complexity. See generally BENJAMIN DOCKTER, URBAN COMPLEXITY: A HOLISTIC APPROACH TO THE DESIGN OF CITIES (2010) (presenting research analyzing the modern design of cities).

54 Hayek indeed recognized this. Speaking on the need for enforcement, he remarked that people "may have to be made to obey, since, although it would be in the interest of each to disregard them, the overall order on which the success of their actions depends will arise only if these rules are generally followed." HAYEK, LAW, LEGISLATION AND LIBERTY, supra note 21, at 45 .

55 For these mechanisms, see supra note 17.

56 See Thomas Hobbes, Leviathan (A.P. Martinich \& Brian Battiste eds., Broadview Press 2010) (1651) (arguing for the necessity of a strong undivided government); see also MICHAEL TAYLOR, THE POSSIBILITY OF COOPERATION 1-2 (1987) (noting that LeVIATHAN, supra, represented the first full expression of this justification for the state).

57 That is, relatively non-intrusive in terms of artificially creating order. 
strengthening it through codification and formal enforcement. Yet, while bolstering enforcement is a common motivation for Formalizing, an equal motivation is the fact that existing customary social order already enjoys widespread compliance, rendering it far easier to codify. Overall, the approach is a very attractive form of legislative minimalism because it simply formalizes order rather than building order from scratch. As such, it sidesteps the problem of informational complexity and design error. Yet it remains highly minimalist. This has, for example, traditionally been the state's approach regarding much of contract law and indeed continues to be an overarching principle. While there are clear exceptions to this, the state's role in contract is radically minimal compared with other areas of law. This brand of legislative minimalism forms the core of the 19th century laissez-faire view of contract law. ${ }^{58}$ I examine the role of minimalism in contract law in Part IV.

It is important to recognize that Formalizing is extraordinarily common. Indeed, the codification of much of the civil law from the tradition of medieval "customaries"-collections of local customary law that were gradually codified by local jurists, ${ }^{59}$ of which, the Coutume de Paris is perhaps the most well-known example ${ }^{60}$-represents Formalizing on a truly massive scale. Perhaps the most obvious examples are found in colonial and postcolonial systems where pre-existing indigenous customary social order is incorporated into the legal system. ${ }^{61}$ More generally, the legal importance of customary social order comes to the fore probably most notably in the case of international law where a coherent legal order is gradually gliding into being. In the realm of international law, "custom stands next to treaties as a primary

\footnotetext{
58 The distinguished American legal scholar Roscoe Pound once described this approach stating that "the law was conceived negatively as a system of hands off while [people] do things rather than as a system of ordering to prevent friction and waste." LiNDA MULCAHY \& JOHN Tillotson, Contract Law IN Perspective 34 (4th ed. 2004). The laissez-faire belief as encapsulated in freedom of contract, however, has been dramatically curtailed since the 19th century. See P. S. AtIYAH, The Rise and Fall of Freedom of ConTRaCt (1979) (illustrating how, grounded upon basic notions of fairness, the growth of consumer protection and employment legislation has limited freedom of contract). I revisit this later in the paper. See infra Part IV.B. This minimalist view is of course especially prevalent among those of a libertarian persuasion. See, e.g., NozicK, supra note 16, at 26 (setting forth the classical libertarian view of the minimalist state).
}

59 For a good overview of the absorption of customary law into the civil law, see JOHN HENRY Merryman \& Rogelio Pérez-Perdomo, The Civil Law Tradition: An Introduction to the LEGAL SYSTEMS OF EUROPE AND LATIN AMERICA 20-26 ( $3 \mathrm{~d}$ ed. 2007).

60 I refer the interested reader to JeAn TRONÇON, COUTUME DE LA VILLE ET Prevoté (1618). Similarly, see the use of medieval English "custumals," textual compilations of the local social customs of a manor or town. See BrITISH Borough ChARTERS 1042-1216, at xvii (Adolphus Ballard ed., 2010).

61 For example, the South African Recognition of Customary Marriages Act 1998 recognized customary marriages, preserving its legality. Recognition of Customary Marriages Act 120 of 1998 (S. Afr.). 
source of law." ${ }^{\prime \prime 2}$ The fact that custom is paid so much overt deference in the field of international law may be attributed to the absence of a central legislative authority-there are really few alternatives.

In case the prevalence of Formalizing is not immediately obvious, let me provide some more examples. Indeed, history is replete with lessons in Formalizing. I will present examples drawn from disparate quarters of law to support my argument (something I do throughout the paper). A great illustration of Formalizing is the case of the medieval law merchant, the lex mercatoria, which gave rise to a complex system of order, i.e. business customs, which national laws to a great extent later co-opted and codified. Indeed, the most basic principles of contract such as formation, content, misrepresentation, mistake, and duress, as well as the incorporation of notes and bills or exchanges, arose originally not through the complex mechanics of legislation, but from the customary rules of merchants, only to be later co-opted by nation states and codified. ${ }^{63}$ The historical rules governing international shipping, the lex maritima, is another good illustration of Formalizing. The lex maritima, developed transnationally over a number of centuries as an extension of the law merchant. The lex maritima was a body of oral rules, customs, and usages relating to navigation and maritime commerce arising in medieval Western Europe from the 9 th to the 12 th centuries. ${ }^{64}$ The lex maritima was eventually absorbed into domestic laws through legislative processes. ${ }^{65}$ The effect of Formalization was a strengthening of this system of customary law. ${ }^{66}$ The lex maritima survives today as the core constituents of much contemporary maritime law, particularly the maritime law of the U.K., the United States, and Canada. $^{67}$

Another great example of Formalizing is the law of war, jus in bello. The law of war is derived from a conglomerate of customary rules that percolated up through the long and bloody history of armed conflict, finding

\footnotetext{
62 Francesco Parisi, Spontaneous Emergence of Law: Customary Law, in 5 ENCYCLOPEDIA OF LAW AND ECONOMICS 603, 603 (Boudewijn Bouckaert \& Gerrit De Geest eds., 2000), available at http:// encyclo.findlaw.com/9500book.pdf.

63 See Robert D. Cooter, Structural Adjudication and the New Law Merchant: A Model of Decentralized Law, 14 INT'L REV. L. \& ECON. 215, 216 (1994), available at http:/works.bepress.com/cgi/viewcontent.cgi?article=1050\&context=robert_cooter (speaking about the absorption of merchant practices into the English common law); see also LEON E. Trakman, The Law Merchant: The Evolution of Commercial Law 23 (1983) (discussing the co-opting of merchant practices into both the civil and common law systems).

64 William Tetley, The General Maritime Law-The Lex Maritima, 20 SYRACUSE J. INT'L L. \& CoM. 105, 109 (1994).

65 For a good overview of this process of formalizing, see $i d$. at 110-12.

66 See id. at 110.

67 See id. at 144.
} 
formal codification only relatively recently. ${ }^{68}$ The law of war is a fascinating dynamic when one stops to really consider it: even within the fevered grip of conflict, customary social order emerges to set codified parameters to organized barbarism. That customary rules emerge between combatants in a self-imposed fashion speaks to the unremitting power of customary social order: even antagonists bent on mutual destruction, operating in the complete absence of a central authority, nevertheless coalesce around a system of customary rules to regulate their hostilities. Clearly, these are not parties aiming to create a system of cooperative order. Nevertheless, robust customary social order-the rules of war-arises (quite reliably in fact) upon the bloody and chaotic landscape of conflict. ${ }^{69}$ The international process of codification began in earnest in the mid-19th century with the first Geneva Convention. ${ }^{70}$ The Geneva Conventions and additional protocols are excellent examples of Formalizing in that they largely codified pre-existing, widely adhered to customary rules of war, i.e. international norms for humanitarian treatment in war. ${ }^{71}$ Likewise, the Hague Conventions codified many pre-existing norms of military conduct. Indeed, the Hague Conventions are quite explicit that Formalizing was one of its main goals: "to revise the laws and general customs of war, either with the view of defining them more precisely or of laying down certain limits for the purpose of modifying their severity as far as possible.,"72

\footnotetext{
68 For an excellent, yet concise, overview of the history of $j u s$ in bello, see DAVID CAVALERI, LAW OF WAR: CAN 20TH-CENTURY STANDARdS APPLY TO THE GLOBAL WAR ON TERRORISM? 31 53 (2009), available at http://www.au.af.mil/au/awc/awcgate/army/csi_cavaleri_law.pdf (Global War on Terrorism Occassional Paper 9).
}

69 An extraordinary example of the power of customary social order, even between adversaries, is that of soldiers on the Western Front in WWI. Truces were quite common between Allied and German units that had been facing one another for long periods of time and fought repeated internecine battles over the same territory. In these conditions, complex "systems of communication developed to agree terms, apologize for accidental infractions and ensure relative peace-all without the knowledge of the high commands on each side .... Raids and artillery barrages were used to punish the other side for defection ..." MATT RIDLEY, THE ORIGINS OF VIRTUE: HUMAN INSTINCTS AND THE EVOLUTION OF COOPERATION 65 (1997).

70 Though it should be noted that the Paris Declaration Respecting Maritime Law, abolishing privateering, came into force eight years earlier in 1856. Paris Declaration Respecting Maritime Law, Apr. 16, 1856, available at http:/www.icrc.org/applic/ihl/ihl.nsf/385ec082b509e 76c41256739003e636d/19ee2533111 f9e2ec125641a004b25ba?OpenDocument.

71 M. Cherif Bassiouni, The Normative Framework of International Humanitarian Law: Overlaps, Gaps, and Ambiguities, in 2 InTERNATIONAL CRIMINAL LAW 493, 507 (M. Cherif Bassiouni ed., 2008); Jean-Marie Henckaerts, The Development of International Humanitarian Law and the Continued Relevance of Custom, in THE LEGITIMATE USE OF MILITARY FORCE: THE Just War Tradition and the CUStomary Law of ARMED Conflict 117, 118 (Howard M. Hensel ed., 2013).

72 Hague Convention (II) With Respect to the Laws and Customs of War on Land and Its Annex: Regulations Concerning the Laws and Customs of War on Land, Preamble, July 29, 1899, available at http://www.icrc.org/applic/ihl/ihl.nsf/Article.xsp?action=openDocument\& 
The Lieber Code during the American Civil War (also known as Instructions for the Government of Armies of the United States in the Field, General Order No.100) is considered to be the first official codification of the laws and customs of war. ${ }^{73}$ Yet, ultimately, the Lieber Code simply reflected the customs of war prevailing at that time. ${ }^{74}$ It did not create new rules-it simply formalized existing ones.

History is littered with countless examples of customary social order being absorbed and transformed into formal law. And this trend may be observed today where it continues unabated in an international context. For example, Formalizing is quite evident in modern codification efforts, such as UNCITRAL, UNIDROIT, CISG, the Lando-Principles, and the UCC, which are but formal reflections of pre-existing commercial practices-the Formalizing of existing systems of order. ${ }^{75}$ Commerce is a form of social interaction so important that the state deems it necessary to bestow upon it formal enforcement mechanisms to shore up existent systems of order. Yet, this is not merely reserved for modern law of an international flavor. Indeed, at its heart, modern criminal codes are (for the most part) massive projects of Formalizing: the codification of highly normative social rules.

Formalizing allows for more reliable enforcement. In fact, having arisen organically, customary systems are often already largely selfenforcing. ${ }^{76}$ Yet the actual enforcement component of Formalizing may, in fact,

documentId=9FE084CDAC63D10FC12563CD00515C4D. The first part to this excerpt ("defining them more precisely") speaks to my point. The remainder of the quote implies a degree of Fine-tuning. I discuss Fine-tuning below.

73 Mark E. Neely, JR., The Civil War and the Limits of Destruction 36 (2007).

74 Id.

75 See Klaus Peter Berger, The New Law Merchant and the Global Market Place, in THE Practice of Transnational Law 1, 12-14 (Klaus Peter Berger ed., 2001); see also Bryan Druzin, Law Without the State: The Theory of High Engagement and the Emergence of Spontaneous Legal Order Within Commercial Systems, 41 GEO. J. INT'L L. 559, 561 (2010) (positing a theory, high engagement theory, explaining the ability of commerce to generate and sustain decentralized legal order).

76 See, e.g., Robert C. Ellickson, Order Without LaW: How Neighbors SETtLe DisPutes (1994) (citing informal enforcement mechanisms amongst cattle ranchers in Shasta County, California). This theme is also an old one in sociology. See, e.g., JEROLD S. AUERBACH, JUSTICE WITHOUT LAW? (1983) (documenting the evolution of informal control mechanisms and attempts by lawyers to undermine or appropriate them); Douglas W. Allen \& Dean Lueck, The "Back Forty" on a Handshake: Specific Assets, Reputation, and the Structure of Farmland Contracts, 8 J.L. ECON. \& ORG. 366 (1992) (discussing the use of simple farmland contracts in place of complicated and expensive alternatives); Lisa Bernstein, Opting Out of the Legal System: Extralegal Contractual Relations in the Diamond Industry, 21 J. LEGAL STUD. 115 (1992) (exploring a system of private governance that has developed in the diamond trade); Janet $\mathrm{T}$. Landa, $A$ Theory of the Ethnically Homogenous Middleman Group: An Institutional Alternative to Contract Law, 10 J. LeGAl STUD. 349, 351 (1981) (developing a theory of the ethnically homogenous middleman group "using a property rights-public choice approach and drawing on the economics of signaling"); Sally Falk Moore, Law and Social Change: The Semi-Autonomous 
not be as important as the mere act of Formalizing. This is something that is easily missed. Codifying an existent system of rules is in itself socially useful in that it clarifies the rules for participants already willing to comply but unable to perfectly coordinate (a coordination game as it is called in game theory). ${ }^{77}$ This is a largely unappreciated aspect to codification. Typically, the focus is upon the enforcement advantages codification brings; however, Formalizing serves a crucial function in simply providing clarity. The law of war may be a good illustration of my point: actors may wish to abide by certain rules (because it is in their mutual interests to do so), but so long as these norms are not clearly acknowledged, a contestant in battle may hesitate. This is true for all the actors and so compliance may falter. In these situations, concrete enforcement mechanisms take a backseat to the simple act of codification. Just making the rules clear can have a powerful impact in terms of compliance, much like how the Oxford English Dictionary clarifies the English language for speakers already eager to comply with whatever the lexiconic rules of the day are. The Oxford English Dictionary does not create; it merely codifies. (In fact, it often significantly lags behind the self-ordering process of the English language.) It boasts no enforcement mechanisms yet nevertheless serves an invaluable regulating function in codifying a pre-existing system of spontaneous linguistic order. ${ }^{78}$ An example of the above point is law formally recognizing left or right-hand drive (a coordination game). The simple act of codification (and thus clarification) of the rule is enough to generate compliance, as all drivers (for obvious reasons) are eager to comply with whatever the rule is. ${ }^{79}$ Indeed, driving on a particular side of the road rarely needs to actually be enforced; it simply needs to be declared.

Social Field as an Appropriate Subject of Study, 7 LAw \& Soc'y REv. 719 (1973) ("argu[ing] that an inspection of semi-autonomous social fields strongly suggests that the various processes that make internally generated ruled effective are also often the immediate forces that dictate the mode of compliance or noncompliance to state-made legal rules").

77 For a fascinating treatment of this idea, see Richard H. McAdams, A Focal Point Theory of Expressive Law, 86 VA. L. REV. 1649 (2000) (using game theoretic terms to explain how systems of order can emerge from law, merely creating focal points without the need for actual enforcement). McAdams's approach borrows conceptually from the work of Thomas Schelling on focal points. For the idea of focal points and salience, see THOMAS C. SCHELLING, THE STRATEGY OF CONFLICT 54-58 (1960).

78 Similarly, the treaties and conventions that enshrine the law of war do not boast genuine enforcement mechanisms. It is that such rules will be reciprocated that gives such codification efficacy. They are largely "self-enforcing agreement[s]," i.e. treaties where "[r]eciprocity and reputation are the key enforcement mechanisms." Beth Simmons, Treaty Compliance and Violation, 13 ANN. REV. POL. SCI. 273, 275 (2010), available at http://www.annualreviews.org/ doi/pdf/10.1146/annurev.polisci.12.040907.132713.

79 McAdams actually goes on to demonstrate how this may also hold true in games other than games of pure coordination. See McAdams, supra note 77. 


\section{Fine-Tuning}

The third option is less ideal, as it involves a degree of regulatory intrusion, yet it is often required. Here the state tweaks the emergent pattern on a structural level, targeting particular design errors while allowing the bulk of the system to function mostly unimpeded by regulation. We can refer to this form of legislative minimalism as Fine-tuning. This is necessary in some situations because there is no guarantee that grown order does not suffer from inefficiencies. Fine-tuning is appropriate where a small structural change can notably increase the system's efficiency. Fine-tuning represents a significant step along the continuum of legislative minimalism, as it is a substantial jump in the level of intrusion. While Formalizing does not seek to alter the social patterning, seeking instead to merely reinforce and strengthen it, ${ }^{80}$ Fine-tuning, in contrast, attempts to remedy system inefficiencies stemming from design error. These inefficiencies may be the result of exogenous changes in the environment, rendering previously efficient systems inefficient, or it may simply be that despite its organic emergence, the system was never entirely efficient (yet was sufficiently efficient to sustain itself). As game theory suggests, bottom-up social patterning may give rise to multiple equilibria; however, these may be quite sub-optimal. ${ }^{81}$

A good example is the driving norms of many third-world cities. For the most part, these systems of order arise bottom-up. While ostensibly chaotic, this traffic order is functional. The traffic moves. Yet these roads suffer from severe yet preventable traffic congestion. Faced with these traffic patterns, governments often institute policies of Fine-tuning. Driving rules are fine-tuned in certain respects in order to increase the efficient flow of traffic, while the majority of these bottom-up "rules of the road" are de facto left in place through lax enforcement. The system of order is largely functional, yet it can benefit enormously in terms of efficiency with just a little strategic Fine-tuning: traffic lights at key intersections, etc. Even in the highly-regulated roads of developed cities, a tremendous amount of traffic patterning is left up to natural ordering. Indeed, the vast majority of it. This is not immediately obvious but becomes clear upon reflection. Take, for example, the case of speeding. In theory, regulators could prescribe a precise driving speed for every inch of the road predetermined as optimal to minimize accidents. However, this would be extraordinarily difficult to determine (and enforce) and indeed debilitatingly

80 Yet this may not be so simple: because Formalizing will change the dispute resolutions available, it may therefore, in fact, change the ex ante patterning. This will likely be the case even if it is simply an expectation that the customary patterning will eventually be formalized.

81 I am referring here to what is known in game theory as the folk theorem. See Drew Fudenberg \& Eric Maskin, The Folk Theorem in Repeated Games with Discounting or with Incomplete Information, 54 ECONOMETRICA 533 (1986), available at http://www.eecs. harvard.edu/ parkes/cs286r/spring06/papers/fudmaskin_folk86.pdf. 
complex when one factors in the ceaselessly shifting traffic conditions. However, what regulators do is set an upper and lower limit to speeding. Speed patterns are then left to naturally self-organize within this prescribed range. In the case of the strategy of Fine-tuning, the customary social order is not left to freely self-pattern nor is it targeted for elimination-it is simply redirected and tweaked along the margins. The total elimination of customary social ordering is the goal of the fourth strategy, to which we now turn.

\section{Dismantling}

The fourth option we can term Dismantling. I call it this because it is the complete dismantling of a pre-existing system of order. There may be several reasons for the state to engage in Dismantling. There is no guarantee that bottom-up ordering will be efficient. Indeed, from a societal perspective, it may be profoundly sub-optimal. Situations such as these may be understood as a form of market failure in the marketplace for customary social order. Alternatively, the system of customary social order may be highly efficient yet be so fundamentally contrary to public policy that Dismantling is necessary. In either case, however, Dismantling should be used only as a measure of last resort and, as a general policy, avoided wherever possible. This is because it is not only highly vulnerable to design error, it may also often require considerable resources to implement, as it is, in essence, the state battling against a pre-existing system of social order. The 18th Amendment of the U.S. Constitution and the disastrous project of Prohibition in the early 20th century is a good example of how difficult Dismantling may be. Not only were the economic costs of Prohibition extraordinarily high, legislatively meddling with a highly complex system such as patterns of alcohol consumption had serious, unpredicted consequences: it unhealthily distorted drinking habits (consumption of hard-liquor actually increased in many places), ${ }^{82}$ increased deaths related to alcohol poisoning (due to the substandard quality of blackmarket alcohol), ${ }^{83}$ and birthed vast organized crime networks related to the illegal production and distribution of alcohol. ${ }^{84}$ These were all unanticipated negative externalities. In fact, prohibition is an excellent example of the problem of informational complexity and the dangers of imposed social order.

Dismantling as a matter of policy, however, is often necessary. For example, a self-ordering normative system that institutionalized racial discrimination, having evolved due to an imbalanced power structure, would

\footnotetext{
82 Harry G. Levine \& Craig Reinarman, Alcohol Prohibition and Drug Prohibition: Lessons from Alcohol Policy for Drug Policy, in DRugs AND SocIETY: U.S. Public Policy 48 (Jefferson M. Fish ed., 2006).

83 Sean Dennis Cashman, Prohibition: The Lie of the Land 255-56 (1981).

84 Mitchel P. ROTH, CRIME AND PUNISHMENT: A History OF THE CRIMINAL Justice SySTEM 230 (2010).
} 
cry out to be remedied through top-down law. ${ }^{85}$ The outlawing of slavery under the Thirteenth Amendment to the U.S. Constitution, a highly complex system that had existed for well over 200 years, and later desegregation through the Civil Rights Act of 1964 are good examples of such systems of customary order. The ancient Hindu caste system of India was a robust customary system of social stratification that existed for millennia yet was systematically dismantled through legal and social initiatives. The Indian Constitution enacted in 1950 with its explicit prohibition on caste discrimination (Article 15) was aimed at the complete dismantling of the caste system. ${ }^{86}$ Customary social order may be highly efficient, robust, and internalized but nevertheless grossly unjust. Thus, the state may need to dismantle such order. Vast, decentralized drug-trafficking networks are highly efficient self-ordering systems; ${ }^{87}$ however, this alone does not justify their continued existence. In some situations, efficiency should be sacrificed for issues of justice. However, by the same token, sometimes justice may itself be a matter of efficiency. ${ }^{88}$ When exactly to dismantle systems of customary social order is an extremely thorny question. When the law is taken as a whole, however, Dismantling is actually not as common as one would think. Indeed, law mostly engages in the first three options (Non-interference, Formalizing, and Fine-tuning), harnessing the energy of pre-existing customary social order rather than opposing it.

\section{E. Concocting}

Sometimes arising in the aftermath of Dismantling, but also emerging in isolation, is what we may call Concocting. This is where the state simply creates legal order from scratch where there was no pre-existing system of customary order. It artificially constructs order. Examples of this form of legislating include the creation of a tax code, the patent system, and other such synthetic artifices concocted by the state. ${ }^{89}$ These are quintessential expressions of legislative maximalism. Because it does not build on any pre-existing natural

\footnotetext{
85 Such normative evaluations, however, vary by society and time-period.

86 BRIJ KiShORE SHARMA, INTRODUCTION TO THE CONSTITUTION OF INDIA 76 (4th ed. 2007).

87 See Jana S. Benson \& Scott H. Decker, The Organizational Structure of International Drug Smuggling, 38 J. CRIM. JUST. 130 (2010) (showing that such networks often display a "general lack of formal structure" and are "composed of isolated work groups without formal connections').

88 Certainly, scholars of a normative law and economics persuasion would agree, particularly in regards to allocative efficiency.

89 Yet even our modern tax codes are, at their core, extensions of archaic systems of rentseeking that no doubt predate the emergence of the state or are decentralized systems of taxation that coincided with the existence of the state, such as tax farming systems. See HIRONORI ASAKURA, WORLD HISTORY OF THE CUSTOMS AND TARIFFS 199-207 (2003) (presenting a historical overview of the end of tax farming in England). Certainly, even complex taxation systems owe their origins to spontaneous ordering patterns of some kind.
} 
order, legal creation of this kind is highly prone to design error. It is a purely artificial creation. And herein lies the fundamental problem with top-down legal order: it does not, as this paper advocates, strategically utilize pre-existing customary social order. From the perspective of design-efficiency, Concocting is often really the very worst form of legal order. When it is fairly large in scope, it often just creates a bloated, complicated mess of inefficient rules-a tangled skein of disjointed regulation.

Yet Concocting too is sometimes necessary. Fortunately, of the five strategies, it is actually the least employed. ${ }^{90}$ For the most part, imposed legal order builds upon and incorporates patterns of customary social order. We see this rather clearly with the strategies of Formalizing and Fine-tuning. Together with Non-interference, they are the most common techniques of governance. Dismantling and Concocting are comparatively rare. Legal maximalism is atypical, and indeed, complete legal maximalism does not really exist. The vast bulk of social order remains unregulated: sleeping patterns, copulation patterns, etc. Indeed, complete legal maximalism would not only most likely be abhorrent in a normative sense; it is, in fact, a logistic impossibility. There is not, nor has there ever been, a society marked by total legal maximalism.

\section{CLARIFYING THE FRAMEWORK}

\section{A. A Tabulated Comparison of the Strategies}

While these five strategies represent different points along a single continuum of interventionism, they are ontologically distinct. However, this may not always be readily apparent. In some respects the strategies bleed into one another. For example, in some cases, Fine-tuning may appear to demonstrate elements of Dismantling. In other cases, Dismantling may be conceptualized as a form of Fine-tuning, and so on and so forth. ${ }^{91}$ There may even be hybrid strategies that combine strategies. Yet while there can be a degree of overlap, on a fundamental level the strategies are distinct from one

90 Concocting is actually not very common. Indeed, the "rules of law rarely create new forms of human activity; instead, they tend to regulate and modify on-going customary human enterprises." See James Bernard Murphy, Habit and Convention at the Foundation of Custom, in The Nature of Customary Law: Legal, Historical and Philosophical Perspectives 53, 68-69 (Amanda Perreau-Saussine \& James B. Murphy eds., 2007).

91 Part of this problem stems from the difficulty in defining a system. Systems often overlap, interconnect, and subsume one another in highly complex ways, making them difficult to clearly identify. For example, is pedestrianizing a downtown area of a city an example of Dismantling or Fine-tuning? If the system here is defined as traffic in the downtown area then it is Dismantling; if the system is defined as the traffic patterns of the entire city, or country, then it is an example of Fine-tuning. The problem is that what is a "system" largely depends on how we choose to define it. This question opens a conceptual can of worms regarding the definition of a system that spans across the disciplines. Articulating such a definition is the comerstone of systems theory. 
another. To sharpen this point, I provide below a tabulated comparison of the five strategies. The first line of the table contrasts the strategies' methodologies. The second line clarifies how commonly the strategies are employed. The third line uses the example of traffic regulation to give concrete form to the concepts.

Table 1. A tabulated comparison of the five strategies of legislative minimalism.

\section{Non-interference Formalizing Fine-tuning Dismantling Concocting}

\begin{tabular}{|c|c|c|c|c|c|}
\hline Methodology & $\begin{array}{l}\text { Allow the } \\
\text { system of } \\
\text { order to } \\
\text { function } \\
\text { completely } \\
\text { unhindered }\end{array}$ & $\begin{array}{l}\text { Grant formal } \\
\text { status to the } \\
\text { system of } \\
\text { order } \\
\text { (usually with } \\
\text { sanctions) }\end{array}$ & $\begin{array}{l}\text { Tweak the } \\
\text { system of } \\
\text { order on a } \\
\text { structural } \\
\text { level }\end{array}$ & $\begin{array}{l}\text { Totally } \\
\text { annihilate a } \\
\text { pre-existing } \\
\text { system of } \\
\text { order }\end{array}$ & $\begin{array}{l}\text { Create legal } \\
\text { order from } \\
\text { scratch }\end{array}$ \\
\hline Frequency & $\begin{array}{l}\text { Most } \\
\text { common }\end{array}$ & $\begin{array}{l}\text { Extremely } \\
\text { common }\end{array}$ & $\begin{array}{l}\text { Very } \\
\text { common }\end{array}$ & $\begin{array}{l}\text { Not very } \\
\text { common }\end{array}$ & Rare \\
\hline $\begin{array}{l}\text { Traffic } \\
\text { example }\end{array}$ & $\begin{array}{l}\text { Allow traffic } \\
\text { conditions to } \\
\text { emerge } \\
\text { organically } \\
\text { and function } \\
\text { untouched by } \\
\text { regulation }\end{array}$ & $\begin{array}{l}\text { Codify and } \\
\text { enforce the } \\
\text { existing } \\
\text { traffic } \\
\text { patterns that } \\
\text { have } \\
\text { emerged }\end{array}$ & $\begin{array}{l}\text { Introduce } \\
\text { regulation to } \\
\text { modify the } \\
\text { flow of } \\
\text { traffic }\end{array}$ & $\begin{array}{l}\text { Eliminate all } \\
\text { traffic from } \\
\text { the road } \\
\text { system (e.g. } \\
\text { pedestrianize } \\
\text { an entire } \\
\text { city) }\end{array}$ & $\begin{array}{l}\text { Create an } \\
\text { entirely new } \\
\text { system of } \\
\text { transportation } \\
\text { (e.g. based on } \\
\text { light-rail } \\
\text { transit) }\end{array}$ \\
\hline
\end{tabular}

As can be seen in the table, the methodology of each of the strategies is distinct. Non-interference simply allows the system of order to function unhindered. Formalizing grants formal status to the system of order, usually through the use of sanctions. Fine-tuning modestly tweaks the system on a structural level (where doing so can achieve a greater degree of efficiency). Dismantling completely eliminates an existing system of order, and Concocting creates legal order from scratch. Hybrid strategies mentioned above, which combine elements from two or more regulatory strategies, are also possible. For example, logging is often restricted in designated areas for a fixed number of years in order to avoid permanent deforestation but later allowed to resume. This regulatory approach may be conceptualized as a hybrid strategy, combining Dismantling and Fine-tuning: i.e. the system is totally eliminated (Dismantling) yet allowed to later resume (Fine-tuning). The strategies also differ with respect to how commonly they are invoked. What stands out is that as we move along the continuum in the direction of legislative maximalism, the strategies are employed less frequently. By far, Non-interference is the most 
common strategy. Formalizing is the next most common approach. Fine-tuning is also a very common legislative tack. Indeed, the law spends a great deal of its legislative energy here, tweaking pre-existing systems of order with a view to making them more efficient- arguably, the vast majority of formal law deals with natural ordering on this level of discourse. This is not at all the case for the strategy of Dismantling, which is substantially less common. Yet the rarest of these strategies is Concocting.

At the risk of straining our gardening metaphor to the point of snapping (no pun intended): Non-interference is simply letting the plants grow; Formalizing is comparable to reinforcing a growing plant by tethering it to a stick or rod; Fine-tuning is minor weeding or trimming; and Dismantling is completely uprooting a plant, tearing it out from its roots. Concocting does not fit very well into our gardening metaphor. It is, I suppose, comparable to artificially fabricating a plant, perhaps a plastic Christmas tree. In any case, although imperfect, the metaphor captures the strategies available to the legislative minimalist project. These five strategies represent a toolkit into which policymakers can reach and pull out the most optimal legislative strategy, with a view to minimizing unnecessary regulatory intrusion. A clear, conceptually rigorous framework as to how to deal with customary social order is not merely theoretically useful; it is arguably critical given the general trend in the common law towards a greater reliance on statute. ${ }^{92}$ While the law already deals in customary social order, it can benefit enormously from a heavy dose of theoretical clarity so lawmakers can more skillfully work within a minimalist framework.

\section{B. Contract: A Paragon of Legislative Minimalism}

Descending from the lofty heights of theory, this section examines our taxonomy of strategies in the context of a concrete example-that of contract. Contract is, in a sense, a paragon of legislative minimalism. Contract is perhaps the one area of law where the minimalist approach is most evident. ${ }^{93}$ As such, it provides a magnificent case study. Exploring how the state deals with contract may give us insight as to how legislative minimalism may be applied more broadly. While the state's approach to contract is generally minimalist, this minimalism is still tempered. The state adopts policies of Non-interference, Formalizing, Fine-tuning, or even Dismantling depending upon the nature of

92 See, e.g., Gordon R. Woodman, Ghana: How Does State Law Accommodate Religious, Cultural, Linguistic and Ethnic Diversity, in CUltUral Diversity AND THE LAw: STATE RESPONSES FROM AROUND THE WORLD (Marie-Claire Foblets ed., 2010) (discussing the trend in Ghana toward supplementing common and customary law with legislation).

93 For an examination of minimalism in commercial contracts, see JONATHAN MORGAN, Contract Law Minimalism: A Formalist Restatement of Commercial Contract Law (2013) (advocating a minimalist framework to the law of contract). 
the legal order that is created by the terms of the contract. Indeed, contract law is a perfect case study for us as it exhibits most of the strategies of legislative minimalism. Issues of substantive (as opposed to merely procedural) fairness, among other public policy considerations, affect which form of minimalism is invoked. ${ }^{94}$ Indeed, we see most of the strategies of legislative minimalism on display when we examine how the state deals with contract. Contract is also an ideal case study because it is the closest the law gets to institutionalizing the creation of customary social order. Fuller described customary law as the inarticulate older brother of contract. ${ }^{95} \mathrm{I}$ would be inclined to agree. As I envision it here, a contract is a mini-system of order forged by the participants themselves - each contract represents a tiny, self-contained system of bottomup order. The state intrudes upon these systems of order to different degrees, yet the overarching spirit is unmistakably minimalist.

\section{Non-Interference in Contract}

In its general deference to freedom of contract, the state adopts an overarching policy of Non-interference. ${ }^{96}$ The contracting parties are free to create the legal order that they wish, relatively unimpeded by the state, the state's role being merely facilitative. ${ }^{97}$ The classical model of contract assigns the law a non-interventionist role. ${ }^{98}$ The belief is that "parties should enter the market, choose their fellow-contractors, set their own terms, strike their bargains and stick to them." The two linchpins of this approach are "the doctrines of "freedom of contract' and "sanctity of contract." "100 Vital to the doctrine of freedom of contract is "term freedom." 101 This is the principle that the parties are free to set their own terms and at liberty to decide the subject matter and substance of their contract. ${ }^{102}$ The role of law is simply to identify and enforce the parties' agreement. ${ }^{103}$ Freedom of contract has, of course, been significantly curtailed over the last century, as reflected in the neo-classical model of contract. The growth of consumer protection, rent, and employment legislation has put in place limitations on freedom of contract. Notwithstanding

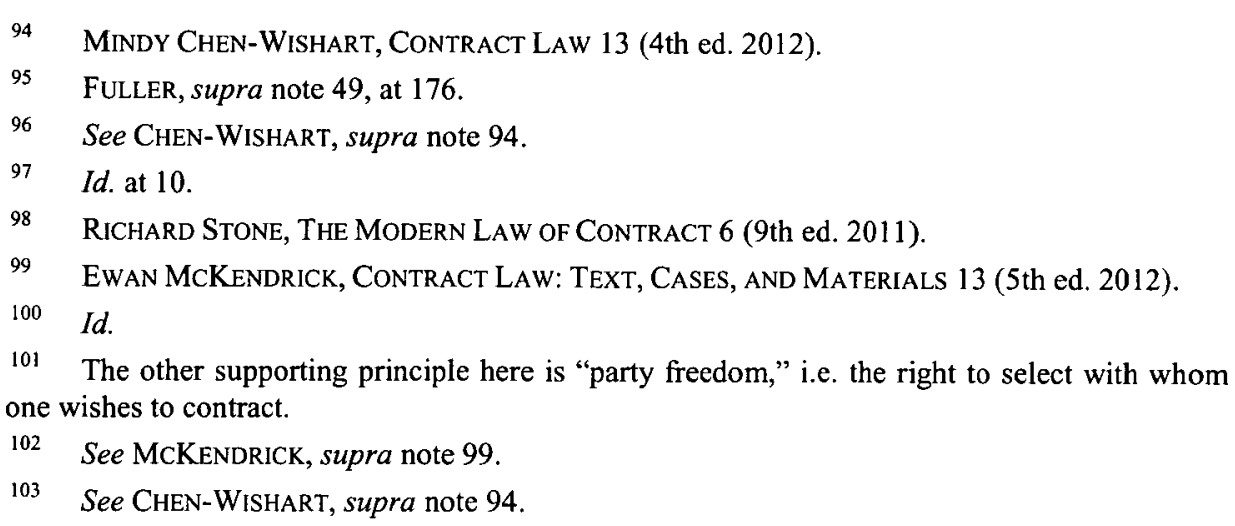


this, however, Non-interference remains a basic feature of contract law, as enshrined in freedom of contract. ${ }^{104}$

\section{Formalizing in Contract}

In that the state will generally enforce the terms of the contract (with certain limitations), ${ }^{105}$ the state engages in a policy of Formalizing. Indeed, the state's role is to give effect to the parties' agreement through enforcement of the contact's terms. ${ }^{106}$ The deference to customary self-ordering is unmistakable. Where the parties' intentions are unclear, this willingness extends to pre-existing custom. Extrinsic evidence of custom is admissible to interpret written contracts with respect to which they are silent. ${ }^{107}$ In such cases, the courts have been more than willing to imply terms on the basis of established trade customs. ${ }^{108}$ As already touched upon, beyond the particular terms of the contract, the state has formalized numerous core principles that initially arose bottom-up as informal rules within commercial communities, such as the incorporation of notes and bills of exchanges. ${ }^{109}$ The parol evidence rule and the doctrine of completeness of writings are further examples of Formalizing. ${ }^{110}$

104 See MCKENDRICK, supra note 99, at 294. For a classic analysis of the transformation of freedom of contract in this respect, see ATIYAH, supra note 58. But see THE FALL AND RISE OF FREEDOM OF CONTRACT (F. H. Buckley ed., 1999) (essays analyzing the resurgent interest in freedom of contract). For the landmark case law regarding freedom of contract in the context of employment legislation, see Lochner v. New York, 198 U.S. 45 (1905) (holding that setting a limit to the hours a baker could work was an "unreasonable, unnecessary and arbitrary interference with the right of the individual to his personal liberty, or to enter into those contracts in relation to labor which may seem to him appropriate or necessary for the support of himself and his family"). Lockner is, however, no longer good law. See West Coast Hotel Co. v. Parrish, 300 U.S. 379 (1937), where the U.S. Supreme Court upheld the constitutionality of minimum wage legislation. West Coast Hotel Co. is regarded as having ended the Lochner-era of contract law in America. West Coast Hotel Co. is an example of Fine-tuning (see below for a fuller discussion). Both landmark rulings are excellent examples as they involve self-ordering in the market, a forum where spontaneous order is often remarked upon.

105 See CHEN-WISHART, supra note 94.

106 Id. at $10,14$.

107 See, e.g., Hutton v. Warren, (1836) $1 \mathrm{M} \& \mathrm{~W} 460$.

108 Id.

109 See TRAKMAN, supra note 63, at 23-27.

110 See Restatement (SECOND) OF CONTRACTS $§ 213$ (1979) (setting out the common law parol evidence rule); see also U.C.C. § 2-202 (2001). 


\section{Fine-Tuning in Contract}

Yet, the state's approach to contract is not completely hands-off. Motivated by interests of fairness and social equity, the state also engages in Fine-tuning. Implied terms are an excellent example of Fine-tuning. Here, we have a deliberate intervention of the court or legislature to regulate the ordering system (i.e. the terms of the contract) created by the parties with the goal of improving the contract. Fine-tuning is captured more broadly in the neoclassical model of contract. ${ }^{111}$ Minimum wage requirements are good examples of Fine-tuning. While the self-ordering system regarding labor earnings in the market place is left relatively untouched (parties are free to set salaries commensurate with the skill level of workers), a floor is put in place in order to correct inherent shortcomings in the system. This is similar to the example given earlier regarding speeding: the system is left to self-order but within prescribed limits. The law tweaks the self-ordering system of market pay along the margins, enacting statutory minimum wage requirements that alter the wage structure in order to achieve a socially preferable distribution of income. Many theorists now question if such laws are, in fact, even effective in achieving these goals. Minimum wage laws have been and continue to be highly controversial and the subject of vigorous debate amongst economists, with many arguing that minimum wage laws are not a good policy tool. ${ }^{112}$ Minimum wage laws are perhaps a good example of the potential for design error of topdown law when tinkering with a spontaneous system of order-in this case, wage patterns in the market. The same story arguably applies to other forms of direct regulation on voluntary exchange, such as family leave laws, sick leave laws, other prescriptions of the Fair Labor Standards Act, anti-discrimination laws, union protections, and so on and so forth.

It is interesting to note how shifting norms and social conceptions of value will determine what the law considers proper grounds for Fine-tuning. Indeed, this is reflected writ large in the shift from a classical to neo-classical model of contract law. Employment standards, a substantive part of employment law, are simply customary norms regarding minimum socially acceptable working conditions. Social norms invariably transform over time; new normative rules emerge, replacing older normative standards. In all areas of law, we can discern the transformative force of evolving custom impacting existing values. However, the specific goals that a society deems worthwhile to pursue are irrelevant to the present thesis in a technical sense: the objective

\footnotetext{
111 See CHEN-WISHART, supra note 94, at 11.

112 For an interesting book-length, empirically-rich discussion along these lines, see DAVID Neumark \& William L. WASChER, Minimum Wages (2008) (arguing that minimum wage laws actually do not achieve the main objectives set out by their supporters). But see DAVID CARD \& Alan B. Krueger, Myth and Measurement: The New Economics of the Minimum Wage (1995) (arguing against the view that higher minimum wages reduce jobs for low-wage workers).
} 
may be to rectify the social injustice of slavery or to institute it more broadly. In any case, the methodology this paper advances remains the same. What is offered here is a descriptive rather than a normative analysis-what is of relevance is how lawmakers can implement the strategies of legislative minimalism on a technical level. The decisive role that value positions will play in this implementation is acknowledged yet remains immaterial to the present thesis.

\section{Dismantling and Concocting in Contract}

The law also engages in Dismantling with regards to contract. For example, vitiating factors, such as duress and unconscionability, can completely invalidate a system of order established through contract. Contracts that conflict with public policy, such as contracts to conduct illegal activity, perceived gross immorality, or contracts of slavery, will be pointedly dismantled by the state. ${ }^{113}$ A great illustration of Dismantling is anti-trust law. Here, the self-ordering systems created by commercial cartels are systematically dismantled under the neo-classical banner of maximizing social welfare through competition. The state simply overrides such systems of selfordering, voiding agreements that restrict market competition. ${ }^{114}$ Dismantling in this form is seen as a matter of public policy: the system of self-order (monopolistic collusion) is deemed to be detrimental. In some jurisdictions, this is true even where price-fixing and other horizontal restraints (such as group boycotts and market division) are a mostly spontaneous arrangement with absolutely no explicit arrangements to engage in price manipulation. In such jurisdictions, even tacit collusion (also termed conscious parallelism) is, in principle, sufficient to warrant antitrust enforcement. ${ }^{115}$ Tacit collusion, unlike cartels, is not criminalized, yet is, "in principle, .. . subject to antitrust enforcement." 116 Indeed, in the case of tacit collusion, coordinated behavior

\footnotetext{
113 See CHEN-WISHART, supra note 94, at 12.

114 Under U.S. law, section 1 of the Sherman Act declares illegal "every contract, combination in the form of trust or otherwise, or conspiracy, in restraint of trade or commerce . . ." 15 U.S.C. $\S 1$ (2012). Under EU law, the Treaty of Lisbon prohibits anti-competitive agreements, rendering any such agreements automatically void. Consolidated Version of the Treaty on the Functioning of the European Union art. 101, May 9, 2008, 2008 O.J. (C 115) 88-89 [hereinafter TFEU].

115 For example, under EU law, tacit collusion could come under the Lisbon Treaty, Article 101 "concerted practices," as well as the principle of "collective dominance" under Article 102. TFEU, supra note 114, art. 101-02.

116 Peter Davis \& Eliana Garcés, Quantitative TeChNiques for Competition and ANTITRUST ANALYSIS 316 (2009). Under section 1 of the Sherman Act, however, tacit collusion is not deemed sufficient to justify state intervention because section 1 requires proof of agreement (conspiracy). 15 U.S.C. $§ 1$; see also Richard A. Posner, Oligopoly and the Antitrust Laws: A Suggested Approach, 21 STAN. L. REV. 1562 (1969) (arguing that antitrust law should regulate consciously parallel oligopoly behavior); RICHARD A. POSNER, ANTITRUST LAw 53-55
} 
emerges in an entirely spontaneous fashion without the need for explicit communication of any kind-a classic illustration of a system of spontaneous self-ordering. ${ }^{117}$

In regard to the strategy of Concocting, we find very little evidence of this in contract. Among the various areas of law, this brand of maximalism is not readily identifiable in contract. This is because state regulation of contract leans so much in the direction of minimalism that full-fledged Concocting as a strategy does not make an appearance. Arguably, some standard form contracts with government agencies where specific terms must be included as a matter of law might be considered as forms of Concocting. Yet this does not meet the criteria of Concocting in its purest sense, i.e. the wholesale construction of a system of order.

Stepping back for a moment, it is important to note that the tactics of legislative minimalism are not restricted to contract. What we do in contract may be applied in all areas of law. Where the line of legislative intrusion should be drawn will unavoidably be affected by normative considerations; however, this long-standing debate need not concern us. We are merely providing a conceptual framework for policymakers who wish to boost system efficiency. Where formal law should step in will often remain open to debate and turn on normative considerations. However, regardless of where one stands in this ideological feud, the chance of design error increases the more we wander away from minimalism. This is not a normative appraisal; it is a factual contention, at least it is the working premise of this Article. From a practical perspective, however, it is not always easy for legislatures to know which strategy is most suitable-for example, when Formalizing is more appropriate than Fine-tuning, or Concocting more appropriate than Dismantling. Ultimately, this will turn on the specific system of order that is being confronted. However, general guidelines can be of enormous help here. Wherever feasible, minimalism should be our starting point-that minimalism is preferable should be a presumption for policymakers. However, where a system of order seems to be failing, or producing unacceptable externalities (this will invariably turn on normative considerations), regulation is necessary. Ever higher degrees of legislative intervention should then be implemented until the situation is sufficiently remedied. To use once more a metaphor: if the construction of a house is defective, the most sensible line of attack is to see if the problem is resolvable through minor tinkering; one should not immediately

(2d ed. 2001) (explaining why tacit collusion did not come to constitute monopolistic practice under U.S. law).

117 See DAVIS \& GARCÉS, supra note 116, at 315 (discussing the idea that coordinated behavior may emerge even without the need for explicit communication); see also HERVÉ DUMEZ \& ALAIN JEUNEMAITRE, UNDERSTANDING AND REgULATING THE MARKET AT A TIME OF GLOBALIZATION: THE CASE OF THE CEMENT INDUSTRY 98-101 (2000) (discussing spontaneous coordination in the cement industry through the exchange of information). 
rip out the foundations of the building and start anew. Adjustments and minor replacements should be first attempted, increasing the level of intrusion only as necessary. Indeed, it may become clear that we, in fact, need to rip up the foundations of the house; however, this should be our last, not our first, course of action. Through incremental legislation, it is possible to hone in on the appropriate degree of intrusion.

\section{Beyond Law: A Wide Breadth of Potential Application}

Before concluding our discussion, one final point should be briefly made. It is important to appreciate that this taxonomy has a wide breadth of potential application. These strategies are not simply limited to the case of legal order; they arise wherever top-down planning attempts to deal with any system of spontaneous order (to use Hayek's term). The same basic approaches arise in, for example, biology, economics, ecology, urban planning, linguistics, chemistry, material sciences, and transportation, to name but a few examples. In all cases, the planner can choose to not interfere with the pattern (Noninterference), reinforce the pattern (Formalizing), redirect or tweak the pattern (Fine-tuning), destroy the pattern (Dismantling), or fabricate a pattern (Concocting). Because systems of spontaneous order surround us, indeed, because life itself is such a system, as autonomous agents standing outside this ordering (to the extent that this is possible), our interactions with spontaneous order are limited to one or more of these five approaches. These are the only options before us. ${ }^{118}$ While our focus here was legal order, exploring how these strategies may be applied in other non-legal contexts may prove quite fascinating. We could see terms such as ecological minimalism, urban minimalism, medical minimalism, psychiatric minimalism, and so on and so forth. ${ }^{119}$ Indeed, it offers a stunningly broad scope of potential application. I leave such avenues of research to those more qualified than I to explore; however, the basic taxonomy for this examination is provided.

\section{CONCLUSION}

While the paper posited a framework for adopting legislative minimalism, the result is not so much a fully-developed theory of how to legislatively deal with customary social order; rather, it provides the framework for one. Indeed, a more intricate methodology could be crafted from this basic model. For the purposes of examination, I assumed the argument regarding informational complexity as valid. (I took what I felt to be the strongest technical argument against centralized design.) This is, of course, open to

\footnotetext{
118 I am including here the various hybrid strategies that are possible.

119 Some of these terms are already in use; however, not in the sense meant here.
} 
debate, but it would be intellectually reckless to simply dismiss it out of hand. I cannot help but think that the temptation to do so is often motivated more by political ideology than intellectual certainty. In any case, if upon examination we determine that minimalism is indeed what we want, the framework I constructed here is a strategic, balanced way to get us there.

The core idea of legislative minimalism is that we could go further in the direction of regulatory non-intrusiveness, trusting instead the self-patterning nature of customary social order. To capture the concept in one simple phrase, it is this: the least amount of law possible. This is the benefit of legislative minimalism: it allows for legislative parsimony. We can soften the hand of law. Yet this is always to be judged cautiously on a case-by-case basis. In some circumstances, we will not be able to break too far in the direction of minimalism; in others, we will be able to engage in extremely high degrees of it. Like any other form of natural ordering, while customary social ordering stands a far better chance of avoiding design inefficiency, it is not always perfect. The system can sometimes generate sub-optimal outcomes, and so we often need to modify it to some degree-we do this in medicine, in agriculture, etc. Cancer cells are the outcome of a natural system as are floods, but we do not hesitate to treat tumors and build flood walls. Social order is no different. Yet this must be done with the utmost humility, aware of our cognitive limitations and mindful that the majority of the time we are but fumbling in the darkness. The hope is that the conceptual framework offered here may serve as a foundation for theorists to build upon and better position policymakers to adopt such a tack so they may fashion leaner, more honed legislation, conceptually clear as to what exactly it is they are doing. 
West Virginia Law Review, Vol. 117, Iss. 1 [2014], Art. 5 